\title{
Coping With Moral Stress in the Swedish Public Services
}

I Elin Thunman'

Researcher in Sociology, Department of Sociology, Uppsala University, Sweden

\begin{abstract}
This paper examines how today's public workers cope with moral stress in organizations where new public management reforms have been implemented. More specifically, the interest is focused on examining which practices are developed in order to fulfill professional standards within the limits of inadequate resources in order to manage moral stress. Case studies at Swedish public work places are analyzed with the help of Lipsky's theory about street-level bureaucrats' coping behavior and theories about the elements of resistance in coping. The main result is the discernment of three dominant modificational strategies to manage stressful moral dilemmas in encounters with clients. The paper contributes to the understanding of coping with moral stress by highlighting that the detected coping forms among a varied group of public professionals imply an active adaption, reification, and opposition to the managerial reforms.
\end{abstract}

\section{KEY WORDS}

Coping strategies / moral stress / new public management / resistance / street-level bureaucrats DOI

10.19154/njwls.v6i3.5528

\section{Introduction}

ajor changes, due to new public management reforms, have occurred in the public services in many Western countries in recent years (Hood, 1995). The new ways of organizing public work have been related to an increase in occupational stress (Chandler et al., 2002; Denton et al., 2002). Studies of public management reforms relate the increased stress levels to various conditions that have followed the implementation of such organizational changes, for instance, ethical conflicts or dilemmas (Raines, 2000). Studies of health care workers reveal that their work situation easily gives rise to a 'moral stress' or 'moral distress' in situations when one knows the ethically correct action to take but feels powerless to take that action because of institutional or other constraints (Corley, 1995; Glasberg, 2007; Raines, 2000; Wilkinson, 1989). Jameton (1984) defined 'moral distress' as a phenomenon in which one knows the right action to take, but is constrained from taking it. Moral stress or moral distress was first recognized among nurses. Moral distress among nurses occurs when the nurse knows what is best for the patient but that course of action conflicts with what is best for the organization, other providers, other patients, the family, or society as a whole (Corley, 2002). Thus, moral distress occurs when the internal environment of nurses-their values and perceived obligations-is

\footnotetext{
${ }^{1}$ Elin Thunman, Department of Sociology, Box 624, Uppsala University, S-751 26 Uppsala, Sweden, E-mail: elin.thunman@soc.uu.se
} 
incompatible with the needs and prevailing views of the external work environment (Epstein \& Delgado, 2010).

Moral stress has later been identified among several health care professional groups, not only as physicians (Austin et al., 2008; Førde \& Aasland, 2008; Hamric \& Blackhall, 2007; Lee \& Dupree, 2008; Lomis et al., 2009), respiratory therapists (Schwenzer \& Wang, 2006), pharmacists (Sporrong et al., 2005), and psychologists (Austin et al., 2005), but also as social workers (McBeath \& Webb, 2002). Between the professions, there appear to be differences in what causes moral distress and in how it is manifested (Austin et al., 2008; Førde \& Aasland, 2008; Hamric \& Blackhall, 2007; Lee \& Dupree, 2008; Lomis et al., 2009; Schwenzer \& Wang, 2006; Sporrong et al., 2005). However, in an overview of the research field, Epstein and Delgado (2010) argue that moral stress is a 'multi-disciplinary problem'.

Moral stress, not the least if the stressful ethical dilemmas related to new public management reforms are considered, may reasonably affect a larger group than health care and social workers. In fact, the descriptions of moral stress have parallels to the sociological theorizing about the street-level bureaucrat's dilemmas. The research about health care and social workers has identified conflicts between professional standards and the organization's resource allocation and requirements as one source of moral stress (Jameton, 1984; Hamric, 2012). Lipsky (2010) describes this conflict in his classic work on street-level bureaucrats as an inherent conflict in these bureaucrats' working conditions. Health care and social workers have with Lipsky (2010, p. 3) be defined as street-level bureaucrats in being: 'Public service workers who interact directly with citizens in the course of their jobs, and who have substantial discretion in the execution of their work are called street-level bureaucrats in this study.' According to Lipsky, the lack of resources is a constant condition for street-level bureaucrats and they develop strategies, or 'coping behavior', to deal with the contradictions of their work. Lipsky (2010, p. 142) emphasizes 'the tendency of street-level bureaucrats to cope with job stresses by modifying their conceptions of work.' Lipsky (2010, pp. 142-156) claims that because all street-level bureaucrats share the same working conditions of chronically limited resources, they also use similar and universal coping-strategies, as rationing services, setting priorities among cases, modifying goals, and dominating clients.

The research about moral stress has put forth several coping strategies, as voicing your opinion, focusing on changes in the work environment, or building support networks, for addressing moral distress (Austin et al., 2005; Epstein \& Delgado, 2010). The street-level bureaucrat perspective highlights other aspects of coping, in which the exercise of discretion plays a decisive role. Focus is more on how the public workers in concrete work situations deal with their daily work in a way that can create a balance between professional standards and the requirements and resources of the organization. This paper brings together the two research areas by exploring moral stress coping with the street-level bureaucrat theory and related perspectives as a departure point. Moral stress coping is examined from the perspective of more public workers' groups than health care and social workers by adding the perspectives of teachers and employment officers. These are professional groups that can be defined as street-level bureaucrats as well (Lipsky, 2010, p. 3). The increase in stress that researchers have associated with new public management reform serves as a background context for the analysis.

In the paper, we ask the question how today's public workers cope with moral stress in organizations where new public management reforms have been implemented. More 
specifically, the interest is focused on examining which practices or, to speak with Lipsky, modifications are developed in order to fulfill their professional standards within the limits of inadequate resources in order to manage moral stress. In addition, we ask if there are common patterns for this sort of modificational coping among various kinds of street-level bureaucrats. By elaborating upon these questions, the purpose of this paper is to contribute to the knowledge about public workers' strategies to cope with moral stress in new public management oriented organizations. Investigating the 'survival strategies' (Bovbjerg, 2011) developed in these organizations is, from a lipskyean perspective, important in order to understand the policies that emerge from practice today. Quite likely, these practices have consequences for both the articulated policy from the top as for clients.

The paper is based on case studies with street-level bureaucrats at different public work settings in Sweden. As a 'late bloomer' when it comes to the introduction of new public management reforms, at least in relation to countries as the UK, Canada, New Zealand, and Australia, Sweden seems like a well-suited departure point. To investigate Swedish workplaces where the managerial reorganizations were relatively recently introduced should give a good opportunity to capture public workers' responses to the changes in power and control. Furthermore, Sweden is one of the European countries where experiences of work stress are most prevalent. The number of employees who reported work-related problems due to stress and other mental tensions has more than doubled during the last decade (Swedish Work Environment Authority, 2015). The increase in stress disorders has been related to the major reorganizations and rationalization in accordance with new managerial rationales and policies during the past years (Gustafsson, 2005; Kälvemark et al., 2004).

The outline of the paper is as follows: Introduction is followed with two sections about the research in the field of coping strategies. Thereafter, the empirical data and the applied methods are described. The next two sections give a portrayal of the implementation of new managerial rationales and directives in the participating work settings. Following these sections, are three sections analyzing the three main forms of modificational coping strategies found in the material. Finally, the connotations for the understanding of the complex relations between power and coping with moral stress and conflicts in public management organization are discussed.

\section{The coping strategies of the street-level bureaucrat}

Street-level bureaucrats interact directly with the citizens in the course of their jobs and deliver the government policies, in the form of benefits and sanctions, to them (Lipsky, 2010, pp. 3-4). This implies a certain amount of discretion and autonomy, since rules and regulations must be interpreted and translated from their programmatic format and applied in consideration with human factors and unique situations (Lipsky, 2010, p. 15). Regulative standards, principles of justices, etc. are sometimes experienced by the street-level bureaucrats as insufficient in daily practice in relation to their own professional values about what is best for the client 'in the long run' (Lipsky, 2010, p. 150). There has always been an inherent conflict between the bureaucracy and the bureaucrat, since the organization seeks control over the work of bureaucrat. Meanwhile, the bureaucracy depends on the bureaucrat's freedom to handle meetings with clients who 
act outside the rules and instead behave in a manner appropriate to the situation. This freedom makes it possible for the bureaucracy to meet long-term goals, Lipsky (2010, pp. 15, 25) argues.

In this way, Lipsky's way of using the concept of discretion is intimately connected to the development of coping strategies to deal with the contradictions of the work. Coping strategies as rationing services, setting priorities among cases, modifying goals, and dominating clients were mentioned above. Lipsky (2010, p. 187) believes that the coping practices are difficult to change because they are conceived as necessary in order to manage the daily work: 'the patterns of practice that develop in this work are rooted in the fundamental coping requirements of the job. These are not easily abandoned or changed because they are experienced by workers and outside observers as vital job requirements. People do not readily give up survival mechanism. This is one of the reasons it is easier to change articulated policy from the top than to change practice from below. Policy articulation from the top is not rooted in defense mechanism developed to cope with the job, while the policy that emerges from practice is rooted in survival.'

The term 'coping' is here referred to adaptive or constructive coping strategies, that is, strategies to minimize or tolerate stress or conflict (Lazarus \& Folkman, 1984, p. 141). In line with Lipsky's use of the term 'coping behavior', the paper concentrates on 'problem-focused' coping strategies, which people use when they try to deal with the cause of their problem aiming at changing or eliminating the source of the stress or conflict (Lazarus \& Folkman, 1984, pp. 152-153).

\section{Coping as resistance}

Lipsky's idea about coping behavior as active modifications of the concepts of work has parallels to the post-structuralist research tradition that highlights the importance of worker subjectivity. Several scholars understand the new public managerial power and strategies as new and more complex forms of control that also involve employee subjectivity. Drawing on the work of Foucault, the 'productive dimension of power' has been highlighted: the modern exercise of power has more complex consequences than forcing or suppressing employees (Clarke \& Newman, 1993; Rose, 1999, p. 165).

In light of the thoughts about new and more complex forms of control in new public management organizations, partly new ways of understanding employee coping have emerged. A central assumption within this emerging field of research is that coping develops new expression in relation to the contemporary exercise of power. Coping should not just be regarded as a passive adaptation, but as an expression of subjectivity as well (Bolton \& Houlihan, 2009; Carls, 2009). Employees are understood as active, meaning creating participants, as the functioning of the work organization depends on their capacity to balance stress and contradictions, even if their capacity to act remains limited (Carls, 2009). For instance, recent studies examine coping as interlinked with resistance. Resistance is not just regarded as a protest but as a coping strategy for achieving adaptation to limited resources and conflicting demands in everyday work as well (Baines \& Cunningham, 2011). People do not simply change their behavior, values, and identity because they become subject to new rules or management goals (Cutcher, 2009; Dixon \& Kouzmin, 1994). Instead, resistance is understood as a 
constant process of adaptation, subversion, and reinscription of dominant discourses (Thomas \& Davies, 2005).

There are several perspectives on the relation between coping and resistance within this evolving area. One field of research describes resistance as one-of several possible-coping strategies. Baines and Cunningham (2011) describe how management expectations on tolerance among workers for 'white knuckle care' has its limits, as the stress and health implications associated with regular violence and abuse, long working hours, intensive work, and poor pay undermine these consent and coping mechanisms, resulting in varied forms of resistance. Workers used their sick time, turned down shifts, or failed to report to work as a means to cope with workplace violence and stress. In a similar manner, Rajan-Rankin (2014) shows in a study of social work students that a variety of coping strategies were adopted, including active resistance, spirituality and faith, critical reflection, and social support.

Another field of research offers a picture of the relation between coping and resistance as even more intertwined. There is neither completely passive subordination, nor pure resistance according to this perspective. Instead, practices of adaptation and appropriation, and of resistance and subordination, must be seen as inherently interlinked. In a survey about teachers' personal web use at work, often considered as 'cyberslacking' or 'Internet abuse', Page (2015) highlights a wide range of reasons for personal web use at work from a means of addressing permeable work-life boundaries and coping with work intensification to providing a virtual space for routine resistance. In an interview study about the flexibilization of work and employment in retailing, Carls (2009) examines employees' ways of balancing in-built contradictions. Using the concepts of 'coping practices', 'common sense', and 'capacity to act', Carls points at the contradictory and interlinked character of employees' coping practices of adaptation, appropriation, conflictive negotiation, and resistance.

A third field of research takes the understanding of coping and resistance as intertwined one step further. Some studies regard the employees' expressions of subjectivity, that is, their coping/resistance strategies, as more or less indirectly beneficial for the organization. For instance, Yakhlef and Essén (2012) reveal how care workers cope with the demands of their unpredictable work by adapting their bodily expressive-responsive abilities innovatively to emerging situational calls. Practice innovation emerges as the outcome of a tension between what it makes sense for the care workers to do based on the practical intelligibility underlying their own practices, on the one hand, and bureaucratic rules and requirements inscribed in terms of economic rationality and cost-efficiency, on the other hand. Because bureaucratic rules are perceived as alienating and unethical, innovation would inevitably be a form of resistance, the authors conclude.

To sum up this far, both Lipsky and the post-structuralist research tradition regard coping as innovating and modificational, or even resistant, responses to inadequate resources and/or conflicting organizational demands. However, moral stress coping has not explicitly been addressed either by Lipsky or the post-structuralist tradition. Furthermore, the intertwined character of coping and resistance has only been empirically examined with specific occupational groups as departure points. These limitations strengthen the importance of gaining more knowledge about the possible common patterns between different kinds of street-level bureaucrats to cope with moral stress in their daily work. 


\section{About the study}

The material is derived from a larger comparative study about stress in public and private organizations. The paper is based on the data from the four participating public workplaces: an employment office, a compulsory school, the team managing an educational program at a public upper secondary school, and an elderly care center.

Work-related stress and stress-related illnesses are common among public employees in Sweden (Sundström-Frisk \& Weiner, 2005). Occupational groups with statistically high numbers of work stress and stress-related mental illnesses were well represented at the selected public organizations: employment officers, elementary school teachers, upper secondary school teachers, nurses, assistant nurses, and physiotherapists (Swedish Work Environment Authority, 2015). With Lipsky, these occupational groups can be described as street-level bureaucrats. The paper draws upon 30 interviews. Five interviews were made at each workplace with members from the occupational groups with high numbers of work stress. One to two management representatives (in total six interviews) and the safety representative (in total four interviews) at each workplace were interviewed as well. Each interview lasted 1 to 2 hours.

The focused semi-structured interviews (Merton et al., 1990) were made up of the following themes: demands on the employees; the employees' complicity and influence regarding the organization's objectives and directives; the implementation of changes and their impact on the working conditions and stress among the employees. This approach sought to balance a thematic structure with opportunities for participants to communicate their own viewpoints (Flick, 1998).

The interviews took place in the workplace during working hours. A potential weakness of the choice of location is the risk that the interviewees withhold critique and other sensitive information. However, in the interview situations, my impression was that the majority spoke openly about their working conditions. One advantage of placing the interviews in the workplace is the ability to gain insight into everyday work.

Some of the interviewees (at least one per workplace), I followed during work as a participating observer (for instance in the classroom). Of course, it was hard to avoid my presence as a researcher affecting the observed (Hammersley \& Atkinson, 1983, pp. 189-190). The observations have nevertheless been valuable, not the least in making it possible to place the accounts of the interviewees in their work context.

Job descriptions, policy documents, and work environment evaluations were collected at the workplaces as well. The aim was to acquire a complementary picture of employees' work content and demands, stress and illness, and the organization's policies, objectives, and guidelines.

The interviews were transcribed and data categorized. The categorization was based on comparisons between the employees at the different work settings, using the comparative method (Glaser \& Strauss, 1967). The search for resemblances and variations was based on a combination of a theory-oriented approach, emanating from the themes and ideas identified in the existing literature (as reflected in the earlier sections of this paper), and an empirically grounded approach in which the theoretical understanding was subject to a critical examination in an reiterated engagement with the material (Silverman, 1985). For instance, studies of the elements of resistance in coping were given more prominence due to the discoveries of the engagement with the material where members from different occupational groups repeatedly spoke in terms of 
'civil disobedience' and 'cheating' when answering questions about coping. A renewed examination of the material discovered various forms of resistance that were not primarily about verbally expressed oppositions to the introduction of managerial policies (although such objections appeared in the interviews). Instead, there were indications that noncompliance could be regarded as a kind of creative act, performed in order to carry out the work in accordance with professional values about the importance of adapting to the help-seekers' particular needs and characteristics. These coping strategies seemed to serve as solutions to stressful moral dilemmas in the daily encounters with clients. Since the participants perceive bureaucratic rules as alienating and unethical, I understand the strategies not only in terms of coping but in terms of resistance as well (cp. Yakhlef \& Essén, 2012).

In the exchange process between theory and empirical data, three main forms of everyday strategies of coping with elements of resistance were distinguished: omittance, revision, and cheating. The three strategies reflect different degrees of modification. Referring to the overlooking of rules, omittance is the most moderate strategy. In standing for an adjustment of the rules, revision is somewhat less moderate. Cheating means a violation of the rules and is the most forceful strategy. These noncompliance practices are discussed after a brief presentation of new public management reforms in Sweden and their specific implementations at the four workplaces.

Of course, there were signs of more 'traditional' problem-focused coping strategies in the material as well, such as a careful planning of the workday, learning new skills to manage the problem, and the use of social support from colleagues (cp. Lazarus \& Folkman, 1984, pp. 152-153). On the basis of the orientation of the paper to explore modificational strategies to deal with moral stress that balance between coping and resistance, more traditional coping problem-focused strategies are not included in the analysis.

\section{New public management reforms in Sweden}

Sweden scores high on new public management emphasis (Hood, 1995). The implementation of the new managerial rationales and policies assumes a variety of appearances in different countries (Almqvist, 2006; Ferlie et al., 1996). In Sweden, rationalization and reorganizations have generally taken place in all public areas, such as the legal system, the national defense, central administration, the school, the health care, and other service producers in the municipalities. Many of the changes during the last decades are effects of the conversion of new steering ideals into new steering methods and organizational structures (Hasselbladh et al., 2008). The practical implementations of the new ideals and their outcomes are not easily defined. However, studies indicate that in Sweden, the public organizational transformations have come to circle around ideas about business management methods and a change from an internal emphasis on bureaucratic rules to a more external orientation, highlighting measurable results and evaluations (Pollitt $\&$ Bouckaert, 2004, pp. 285-289) and introducing the customer concept (Hasselbladh et al., 2008) and exposure to competition (Almqvist, 2006).

The customer orientation and the prominence given to measurable results and evaluations in the Swedish public services are often regarded as related to each other (Gustafsson, 2005; Hasselbladh et al., 2008). In a critical analysis of the customer-oriented reforms in 
the Swedish health care services, Hasselbladh et al. (2008) expose how the management of the organization takes the legitimacy of the professionals to speak for the customer into possession, for instance, through programs to 'put the customer in the center'.

Customer-oriented business management is not a method to ensure that the individual customer's will guides operations. Customer-oriented management consists of systematic methods to control activities toward market-related goals. [...] The encounter with the customer is framed by control regimes where information about the customer and the customer meeting is collected by continuous measurement.

Hasselbladh et al. (2008, p. 71) conclude. That the introduced customer orientation is not primarily on the conditions of the help giver and the receiver is confirmed by the findings in all welfare organizations in the study (see more below).

\section{Organizational framework: the implementation of new managerial rationales and directives}

The past years' introduction of a new public management doctrine in Sweden is evident in all public work settings in the study. The changes that have occurred within the four organizations during the past years confirm the conclusions mentioned above about the dominating character of the public organizational transformations in Sweden. The transformations at the participating organizations have come to circle around ideas about business management methods, emphasizing measurable results and evaluations and customer orientation. The customer orientation is interrelated to an increased standardization through the registration and documentation of customer activities at all the work settings. Below, a short overview of these implementations is presented.

The Swedish Public Employment Service might be seen as a forerunner when it comes to enhanced business management methods and customer orientation since the agency implemented the 'customer' concept in their business. From being a traditional agency with citizen focus, the Swedish Public Employment Service has increasingly become a customer- and result-oriented service agency. The most important task is to meet the labor market requirements of effectively 'matching' job seekers with employers, with a priority to those who are distant from the labor market (The Swedish Code of Statutes, 2007). The authority is, by its 'strategic focus on increasing customer value' (The Swedish Public Employment Service, 2012, p. 66), engaged in development efforts for customers to receive consistent service throughout the country. In 2011, a common basic service to streamline efforts for clients was decided on, evident in the monitoring of enrollees' search activities in standardized ways and the establishment of individual action plans.

At the Public Employment Service's office in the study, located in an immigrant-dense area with many applicants distant from the labor market, open hours have recently been expanded in order to give the customers service. As an effect of the service's enhanced focus on result and goal attainment in terms of successful matching, the officers' work has shifted from the traditional emphasis on supplying jobs to a growing focus on documentation, through automated computerized information systems, of seeking activities and action plans. 
In 2009, a law about freedom of choice for recipients regarding elderly care was implemented (Government Bill, 2008/2009). Exposed to this competition, several municipalities declared their future goal to be a 'world-class' elderly care. In 2011, a 'dignity assurance', based on a 'national value-system', has been introduced to secure the daily care quality for the 'users' (SOU, 2008). The assurance implies an increased focus on the results of operations and follow-up through individual implementation plans and national instruments for needs assessment in order to facilitate a systematic and more uniform approach.

At the participating elderly care organization, the increased customer and result orientation and the exposure to competition are manifested in the implementation of a new value system. The value system is based on the requests of the 'users' as a way to reach the overarching goal to offer a 'world class' elderly care. In accordance with these objectives, the nurses and assistant nurses' work has changed from the traditional emphasis on care to an intensified attention to documentation of the accomplishments in relation to the individual users. The increased documentation was initiated as a way of improving and safeguarding user satisfaction in line with the value system. In order to gain efficiency and results, the amount of care each 'customer' needs is estimated in advance. The nurse assistants have a fixed schedule with specific times for each visit during their workday.

As many other Western countries, the Swedish education system is currently undergoing major restructuring. During the 1990s, the state promoted school choice and competition through legislation and funding of independent (private) schools (Government Bill, 1991/1992; 1992/1993), even though education in Sweden has traditionally been a public issue and students have been enrolled in the (municipal) school in the area where they live. In addition, the school is characterized by higher demands on goal and result attainment and evaluation of pupils' achievements, formulated in the new school programs in 2011 (The Swedish National Agency for Education, 2011a, 2011b).

At the compulsory school in the study, located in an immigrant-dense area with many pupils with a poor Swedish vocabulary, the teachers' work has been altered from the traditional prominence given to teaching to an increased emphasis on documentation of the pupils' learning outcomes. The heightened documentation demands have been introduced along with the implementation of new technology, such as an Internet-based platform for the standardized registration of results and evaluations. The amplified documentation was introduced as a way of enhancing the pupil's learning undertakings and achieving better learning outcomes, through which better goal attainment for the school is reached.

At the participating upper secondary school, the teachers' work has been reorganized from the traditional subject affiliation system to an organization based on interdisciplinary work teams. The work teams were initiated as a way of increasing pupils' learning activities and accomplishing better learning results. In addition, a mentorship program, where the teacher functions as a mentor for some of the pupils, has been implemented in order to give each pupil an individual treatment and better accessibility and to strengthen the school's competitiveness.

\section{Omittance as a way of coping with moral stress}

In this and the following two sections, the three most common forms of coping/resistance strategies to handle moral stress-omittance, revision, and cheating-among the teachers, 
employment officers, and elderly care workers are exemplified and discussed in relation to the introduced management-oriented ideals and practices at their work settings.

To begin with omittance, omittance is regarded as a strategy to solve the conflict between demands for working in accordance with standardized procedures to achieve measurable results and the public worker's professional assessment or practice. One of the compulsory school teachers depicts how the increased requirements for the documentation of pupil activities and results causes a stressful work situation that she, when opportunity is given, handles by ignoring some of the registration work at the municipal digital platform:

The School Web was down for a week and it wasn't possible to do any documentation. Here I'm going to be a little civil disobedient. I'm not going to enter the absence during that week. Because I do not think I have the time, as it will take really long time. One must sit and click for every kid and every lesson for a whole week. So there I say: 'No thanks, I won't do that'. This is actually the teacher's dilemma, that it is so hard to see your own limits. The teacher's work never ends. You can always do more for the pupils. This makes it hard to say stop, and say: 'I've actually been working, as I can no more now. You are allowed to quit now.' But then it starts up here ... because you are never off duty up here [pointing to her head]. There is always says: 'What should I do about this pupil?' [...] Up here [pointing to her head] it's never quiet. Thank God, have I been able to sleep pretty well, except for the last days. But I have had to start with these happy pills to manage the work. I just got depressed all the time.

The teacher uses what she calls her 'civil disobedience' together with other solutions as medication as a way of reducing the stress she experiences. One source of stress is obviously the conflict between professional demands on a moral responsibility for her pupils and the school's documentation demands. The interview material from all the participating work settings indicates that omittance is often associated with the experience of a moral dilemma. For instance, one of the employment officers describes how her judgment of the applicant's needs sometimes conflict with the requirements for matching and measurable results and how she handles the tension by not prioritizing the registration work, an action she characterizes as noncompliance:
A little civil disobedience is evoked in me when the management just declares things: 'Now everybody shall correct, it should be the right number here.' I am a good administrator, at least in my opinion, but since the workload is so heavy, in the end you sometimes have to make some priorities, I think. You take these things with a grain of salt. [...] For me, it is not absolute that I should press every button in the registration system when the situation is acute for the jobseeker. Perhaps someone is upset or has not received his money and is not getting food.

The officer's acts of resistance-what she as well calls her 'civil disobedience'-toward the documentation tasks might be seen as an answer to the organization's orientation toward giving measurable results and the documentation of the encounter with the job applicant and the applicant's activities a prominent position. To use Evetts' terms, the noncompliance seems to emanate from a perceived opposition between the officer's identity and judgments as a professional (for instance, expressed in 'I am good 
administrator, at least in my opinion') and the standardizing motives of the organizational professionalism. The officer's motives are rather based on a traditional and professional ideology (Evetts, 2003), where empathy and individual concern are regarded as important skills:

You don't see many soft values, even if we have a job where it is most important with these things. One looks at the number of cases. But still, I think it is generally known that as an administrator, you need to have these good qualities: good treatment and the right way to communicate and motivate, and such things. But still one talks about these other kind of things, numbers and stuff. Everybody shall be matched. Everyone should be out on a job. You feel stressed when you work and look individually and then the manager comes and says: 'No, no, we have to think about the matching'.

The quotation above reveals that the employment officer's omittance is motivated by altruistic and professional values. Consequently, the omittance might be regarded as a stress-coping strategy with moral overtones based on a professional identity. Lipsky (2010, p. 144) regards altruism as a central aspect of street-level bureaucrats' work incentives: 'Street-level bureaucrats often enter public service with some interest in client-oriented work, embrace professional orientations that call for altruistic behavior towards clients, and continually interact with clients.' He continues: 'They rationalize ambiguities and contradictions in objectives by developing their own conceptions of the public service.' The question is whether the teacher's and employment officer's prioritizing actions might be understood as a mere rationalization of ambiguities and contradictions. The set of rules seem rather clear. Their thoughts about their actions in terms of 'civil disobedience' reveal that they do not experience these acts as sanctioned discretion, based on the interpretation of ambiguous rules or directives. Still, they do not deliberatively break the rules. Rather, their actions are motivated by a flexible and critical attitude toward what they perceive as unethical bureaucratic rules about registration and documentation. Thus, these kinds of actions should be considered as a form of rule bending and an expression of subjectivity. The conclusions are supported by the outcomes in previous studies. In a study about 'deviant' social work, a 'positive deviance', that is, behavior with professional and altruistic motives, is distinguished (Carey \& Foster, 2011). A study about rule bending among nurses discusses an altruistically driven 'responsible subversion' (Hutchinson, 1990). This altruistically motivated noncompliance can be understood as reflecting an image of professionalism based on a social or public service ethos and the associated principle of providing a service on the basis of need (Ackroyd et al., 2007; Lawton, 2005). Apparently, the need-oriented service ideals, related to an occupational professionalism, are at variance with the customer-oriented standardization. On a micro level, this value conflict takes the shape of stressful dilemmas in everyday work, solved by creative acts of resistance.

\section{Revision as a way of coping with moral stress}

The experiences of one of the nurses at the elderly care center and one of teachers at the secondary school are drawn upon to illustrate the second form of resistance, revision. In the examples, revision is used to cope with the conflict between working efficiently 
and effectively in accordance with economic or other organizational guidelines and acting in accordance with professional ethics. The nurse explains how she rearranges her schedule in order to offer the elderly good care in agreement with her professional ideals and to reduce moral stress:

We have a fixed schedule, but still I do a schedule of my own. I handle my time myself. Some things I do a little fast. And some residents need more time. What I do not like is that we have routines: we shall do this and we shall do that. It stresses me. [...] They [the managers] might be angry with me, but I can only do one thing at a time and then the job gets well done. [...] The residents feel the pressure as well. I do not like that. I do not want to feel stressed and I do not want to make the residents stressed. When you work with people, it's not like working with machines: 'Okay, I'll leave you now, and then I'll come back and continue.' You cannot just leave. You have to finish that help.

The nurse's response might be seen as a disagreement with the settled estimation of time given to each resident since it contradicts her professional values about the importance of considering the situation at hand. The nurse's rearrangement of her schedule might be seen as a reaction to the increased standardization that has followed upon the more quantified approach to the 'customers', giving rise to moral stress.

Another illustration of the revision strategy is obtained from the secondary school. One of the secondary school teachers tells about his experiences of conflicting demands between focusing on teaching and on documentation and measurement of performances.

The problem is that the management says: 'The important thing for you teachers to do, it is teaching'. But then they add: 'And shall you do this as well'. And lots of other administrative stuff is put on. So, what are we actually going to do? Is it really teaching that is important or is it the other things that are important? We teachers are constantly struggling with these kinds of questions.

The teacher describes how he handles these conflicting demands by, in accordance with his professional judgment of what is important in teacher work, deliberatively taking the time to create good social relationships with pupils in order to create a beneficial learning environment. His approach is to do as little administration work as possible:

I try to make time by removing time from the pre- and after work, to get the time for individual pupils, to be able to have a conversation. The time is barely there. But I try to take the time to give these human beings or pupils both an understanding of what they do here [at the school] and how to get better and further develop in their studies.

The teacher can be said to solve the conflict between his professional judgment and the demands of documentation work by bargain down the space for administration for the benefit of socializing with his pupils.

In comparison to the case with the omitting teacher and employment officer, it is even more doubtful whether the nurse's and the teacher's rescheduling should be regarded as rule breaking since they actually perform their injunctive work tasks. Nevertheless, especially the nurse's conviction that her actions might annoy the management shows that she does not experience them as sanctioned acts of discretion. Both of them experience 
the new standards as unethical and alienating, which inevitably gives their coping strategies subversive features. Their rescheduling might rather be understood as another form of rule bending and expression of subjectivity. Similar adjustments are described in a study of the practices of home care in four Nordic countries, which exposed that the daily routines of the home carers were much more flexible than the official descriptions (Vabø \& Szebehely, 2012). Standards have been questioned, negotiated, and ignored, as they have been translated into everyday practice (Dahl, 2009; Vabø \& Szebehely, 2012). Furthermore, Danish and Norwegian studies display that home-helpers have resisted new public management implementations in several ways (Kamp \& Hviid, 2012). Described forms of resistance are acting as a buffer for the disadvantageous effects of a policy tool upon the elderly, going against the specified tasks and time allotted and redistributing time according to the daily needs of the elderly (Dahl, 2009; Vabø, 2006).

\section{Cheating as a way of coping with moral stress}

The third strategy to handle moral stress in everyday work, cheating, can be illustrated by the experiences of one of the compulsory schoolteachers and one of the employment service officers. In the examples, cheating with the results 'solves' the stressful conflict between the requirements for documentation of the pupil's or the job applicant's performances and the public worker's professional assessment or practice.

The teacher describes how she makes reports about learning outcomes without actually teaching the pupils on the subject because of lack of time. A majority of the pupils do not have Swedish as their first language and/or grow up in families where Swedish is not the main spoken language. Consequently, the pupils need more time than is estimated in the national guidelines, the teacher argues:

Of course there must be guidelines and requirements, but different regions vary a lot as well. What is primarily in X city is perhaps secondary here. And therefore, you can never proclaim it should be exact, for example, that the national tests should be exactly as long as for everybody, since our pupils need more time because of the language. I think that the requirements today are unreasonable. To be a classroom teacher has turned impossible. We teachers must learn how to limit the compassion and these stressful demands. We keep quiet about it, but I have, for example now, when I filled in the judgments on the computer about if I believe the pupils will achieve the goals in technology in grade six. I haven't had a single lesson in technology, so this is dishonest. I am a fraud! [...] We teachers at the intermediate stage teach twelve school subjects. To cope with that is an absurdity, not least because of the pupils' language skills.

The actions of one of the employment service officers are another example of the cheating strategy. He describes what he perceives as contradictory organizational demands on more administration and control work (in accordance with the more pronounced goal orientation of the public employment service office) and tasks as helping job seekers far from the labor market. One solution to fulfill the conflicting demands is cheating:

Employment officers are ascribed responsibility for fixing jobs as well as administrating all the activities around a job seeker, but given no preconditions to manage it. We should, 
it is quite strict how to do things with regard to quality, but there are no resources to make even a fraction of the quality controls they say we should do. And if you cannot do it other than by fiddling, then you fiddle and the result, quantitatively, will be good. And then everyone is happy until some journalist writes a newspaper article about it, then it is not funny anymore. It is in the system that you have to cheat a bit and as long as it is not discovered it doesn't matter. In reality, all working hours could be devoted to administration, but to feel satisfied - to feel that I make a difference-I have to work a little offensive as well in order to provide jobs.

The schoolteacher and the employment officer react to what they perceive as conflicting demands, which has accompanied the increased requests for documentation of, for instance, goal attainment in standardized computer programs. Their fake documentation work might be regarded as a form of rule breaking. The rule breakage enables them to reduce moral stress by balancing between acting in accordance with personal professional values by adapting the work performances to the client's needs, in these cases the pupil's need for more learning time and the job applicant's need for work, and to conform to management's goal attainment objectives.

This kind of cheating resembles Knights' and McCabe's results in a case study of the implementation of total quality management at a bank holding company; Knights and McCabe (2000) describe how staff engaged in fiddles to reduce cash errors so as to conform to management's goals to balance the cash.

Such resistance, or expressions of subjectivity, cannot be seen as a challenge to management or as a means to enhance individual earnings. It is simply a matter of managing contradictory situations by bypassing the formal rules or requirements of the job.

Knights and McCabe (2000, p. 432) claim and conclude: 'It is not clear whether employee resistance in our case study should be described as "misbehavin" [sic.]' (Knights \& McCabe, 2000, p. 434). In a similar way, it is questionable whether the teacher's and the employment officer's cheating should be described as misbehaving.

As in Knights' and McCabe's study, it is evident that the public workers' cheating is not driven by self-interest, but rather they are motivated by contributing to, at least what they perceive as, their organization's long-term goals. The employment officer's explanation for his fiddling serves as a good illustration:

I think that I contribute to a labor market in a better balance if I go out to meet employers and tell them how we [the Employment Service office] can give them favorable conditions for hiring for instance a functionally disabled person. But if you do this, then you are loaded with work at the expense of the quality control. But it's worth it ... sometimes. The world gets a little bit more beautiful then and people become a little happier, I think. Increase the gross national product a little bit and that we [the Employment Service office] meet the socio-economic goals.

Fiddling with the numbers can be considered as a way of coping with contradictory demands in a way that enables the expression of subjectivity. The fiddling makes the employment service officer able to realize his professional values about the importance 
of providing jobs. Just like in the study of Knights and McCabe, the acts might be regarded as productive contributions as well oppositions to the organization.

\section{Concluding remarks}

Three common forms of modificational coping strategies developed in order to fulfill professional standards within the limits of inadequate resources have been discerned: omittance, revision, and cheating. These coping/resistance strategies are used among various public occupational groups. The analysis indicated that the strategies function as ways to reduce workers' experiences of moral stress in public organizations characterized by management reforms.

The main motive among the public service workers in the study for using these coping/resistance strategies is to perform their work in accordance with their identity and judgments as a professional. Their actions are based on traditional and professional values where adapting the work performances to the client's individual needs are regarded as important professional skills. However, the coping strategies not only function as ways of practically managing the daily work in order to reduce moral stress. In addition, the analysis indicates that the interviewees perceive their coping strategies in terms of subversion, for example, by talking in terms of 'civil disobedience' and fearing that the manager will get mad. A prominent pattern among the employees in the study is that their ways of coping might contain elements of protest, against what they experience as the employer's lack of morality and inability to embrace the organization's long-term goals.

Hereby, the results confirm earlier research about the elements of resistance in coping. This study contributes to the research by revealing similar coping/resistance strategies for handling moral stress among different categories of street-level bureaucrats in managerially reformed organizations. A recurring theme of their experiences is that the standardizing motives of the organizational professionalism (Evetts, 2003) undermine the power and knowledge associated with expertise. The results indicate that this decline of professional discretion as a result of managerialism give rise to moral coping strategies that may challenge or subvert power.

Nevertheless, the subversive expressions of subjectivity can be understood as productive contributions to the organization as well. By finding 'loopholes' to realize their professional values or judgments, the analysis has shown that employees indirectly contribute to the preservation of the established order. As Lipsky $(2010$, p. 23) underlines about the contradictory demands on street-level bureaucrats: 'Society does not want computerized public service and rigid application of standards at the expense of the responsiveness to the individual situation.' In other words, the reformed organizations can be said to implicitly encourage or urge to more subjectivity, but in partly new, less sanctioned, ways in order to successfully manage contradictory expectations on public organizations. As indicated above, the customer orientation in accordance with new public management oriented rationales is often connected to an increased standardization (registration and documentation of customer activities). Still, not the least to realize long-terms goals, the organizations need another, more flexible approach to the customer as well. For example, this is evident in the case with the employment service officer's experiences that it is built-in the system to fiddle. Maybe the acts of 
opposition reveal that the subjectivity of the street-level bureaucrat is more necessary than ever in public organizations; to perform the delicate balancing act between ambiguous missions of public service and to reduce the interrelated experiences of moral stress. By showing this, the analysis reveals the productive and complex dimensions of power in contemporary organizations. Investigating the 'survival strategies' to handle moral stress is indeed important in order to understand the policies that emerge from practice today.

\section{Acknowledgment}

AFA Insurance, Sweden, supported this work (grant number 100010).

\section{References}

Ackroyd, S., Kirkpatrick, I. and Walker, R. M. (2007) Public management reform in the UK and its consequences for professional organization: a comparative analysis, Public Administration 85(1): 9-26. doi: http://dx.doi.org/10.1111/j.1467-9299.2007.00631.x.

Almqvist, R. (2006) New public management - om konkurrensutsättning, kontrakt och kontroll [New Public Management - On Competition, Contract and Control], Malmoe: Liber.

Austin, W., Rankel, M., Kagan, L., Bergum, V. and Lemermeyer, G. (2005) To stay or to go, to speak or stay silent, to act or not to act: moral distress as experienced by psychologists, Ethics and Behavior 15(3): 197-212. doi: http://dx.doi.org/10.1207/s15327019eb1503 1.

Austin, W. J., Kagan, L., Rankel, M. and Bergum, V. (2008) The balancing act: Psychiatrists' experience of moral distress, Medicine, Health Care and Philosophy 11(1): 89-97. doi: http://dx.doi.org/10.1007/s11019-007-9083-1.

Baines, D. and Cunningham, I. (2011) 'White knuckle care work': violence, gender and new public management in the voluntary sector, Work Employment Society 25(4): 760-776. doi: http://dx.doi.org/10.1177/0950017011419710.

Bolton, S. C. and Houlihan, M. (2009) Beyond the control-resistance debate, Qualitative Research in Accounting and Management 6(1/2): 5-13. doi: http://dx.doi.org/10.1108/ 11766090910940629.

Carls, K. (2009) Coping with control? Retail employee responses to flexibilisation, Qualitative Research in Accounting and Management 6(1/2): 83-101. doi: http://dx.doi. org/10.1108/11766090910940683.

Carey, M. and Foster, V. (2011) Introducing 'deviant' social work: contextualising the limits of radical social work whilst understanding (fragmented) resistance within the social work labour process, The British Journal of Social Work 41(3): 576-593. doi: http:// dx.doi.org/10.1093/bsw/bcq148.

Chandler, J., Barry, J. and Clark, H. (2002) Stressing academe: the wear and tear of the New Public Management, Human Relations 55(9): 1051-1069. doi: http://dx.doi.org/10.1177/ 0018726702055009019.

Clarke, J. and Newman, J. (1993) Managing to survive: dilemmas of changing organizational forms in the public sector. In N. Deakin and R. Page (Eds.), The Costs of Welfare, Aldershot: Ashgate, pp. 46-65.

Corley, M. C. (1995) Moral distress of critical care nurses, American Journal of Critical Care 4(4): 280-285. Available at: http://hdl.handle.net/10755/173128.

Corley, M. C. (2002) Nurse moral distress: a proposed theory and research agenda, Nursing Ethics 9(6): 636-650. doi: http://dx.doi.org/10.1191/0969733002ne557oa. 
Cutcher, L. (2009) Resisting change from within and without the organization, Journal of Organizational Change Management 22(3): 275-289. doi: http://dx.doi.org/10.1108/ 09534810910951069.

Dahl, HM. (2009) NPM, disciplining care and struggles about recognition, Critical Social Policy 29(4): 634-654. doi: http://dx.doi.org/10.1177/0261018309341903.

Denton M., Zeytinoglu, I., Davies, S. and Lian, J. (2002) Job stress and job dissatisfaction of home care workers in the context of health care restructuring, International Journal of Health Services 32(2): 327-357. doi: http://dx.doi.org/10.2190/VYN8-6NKY-RKUM-L0XW:

Dixon, J. and Kouzmin, A. (1994) The commercialization of the Australian public sector: competence, elitism or default in management education? International Journal of Public Sector Management 7(6): 52-73. doi: http://dx.doi.org/10.1108/09513559410070597.

Epstein, E. G. and Delgado, S. (2010) Understanding and addressing moral distress, The Online Journal of Issues in Nursing 15(3). doi: http://dx.doi.org/10.3912/OJIN.Vol15 No03Man01.

Evetts, J. (2003) The sociological analysis of professionalism: occupational change in the modern world, International Sociology 18(2): 395-415. doi: http://dx.doi.org/10.1177/ 0268580903018002005.

Ferlie, E., Ashburner, L., Fitzgerald, L. and Pettigrew, A. (1996) New Public management in Action, Oxford: Oxford University Press.

Flick, U. (1998) An Introduction to Qualitative Research, London: Sage.

Førde, R. and Aasland, OG. (2008) Moral distress among Norwegian doctors, Journal of Medical Ethics 34(7): 521-525. doi: http://dx.doi.org/10.1136/ime.2007.021246.

Glasberg, A-L. (2007) Stress of Conscience and Burnout in Healthcare: The Danger of Deadening One's Conscience, Umeå: Umeå University.

Glaser, B. and Strauss A. (1967) The Discovery of Grounded Theory, Chicago: Aldine.

Government Bill (1991/92) On Freedom of Choice and Independent Schools. Available at: http://data.riksdagen.se/fil/5277FE6D-7C0B-47CB-AE25-7B2234DE5FBE.

Government Bill (1992/93) Freedom of Choice in School. Available at: http://data.riksdagen. se/fil/EB93DF05-0BE2-400C-A8AF-AB89E185204D.

Government Bill (2008/09) Act on System of Choice. Available at: http://regeringen.se/ download/e7303623.pdf? major $=1 \&$ minor $=112556 \& \mathrm{cn}=$ attachmentPublDuplicator 0 attachment.

Gustafsson, R. A. (2005) The welfare of the welfare services. In R. A. Gustafsson and I. Lundberg (Eds), Worklife and Health in Sweden 2004, Stockholm: National Institute for Working Life, pp. 271-295.

Hammersley, M. and Atkinson, P. (1983) Ethnography: Principles in Practice, London and New York, NY: Routledge.

Hamric, A. B. (2012) Empirical research on moral distress: issues, challenges and opportunities, HEC Forum 24: 39-49. doi: http://dx.doi.org/10.1007/s10730-012-9177-x.

Hamric, A. B. and Blackhall, L. J. (2007) Nurse-physician perspectives on the care of dying patients in intensive care units: collaboration, moral distress, and ethical climate, Critical Care Medicine 35(2): 422-429. doi: http://dx.doi.org/10.1097/01.CCM.0000254722.50608.2D.

Jameton, A. (1984) Nursing Practice: The Ethical issues, Englewood Cliffs, NJ: Prentice-Hall.

Hasselbladh, H., Bejerot, E. and Gustafsson, R. Å. (2008) Bortom new public management institutionell transformation i svensk sjukvaird [Beyond New Public Management Institutional Transformation in the Swedish Health Care], Lund: Academia Adacta.

Hood, C. (1995) The 'new public management' in the 1980s: variations on a theme, Accounting, Organizations and Society 20(2/3): 93-109. doi: http://dx.doi.org/ 10.1016/0361-3682(93)E0001-W.

Hutchinson, SA. (1990) Responsible subversion: a study of rule-bending among nurses, Scholarly Inquiry for Nursing Practice: An international Journal 4: 3-17. 
Kamp, A. and Hviid, H. (2012) Elderly Care in Transition - Management, Meaning and Identity at Work. A Scandinavian Perspective, Copenhagen: Copenhagen Business School Press.

Knights, D. and McCabe, D. (2000) Ain't misbehavin'? Opportunities for resistance under new forms of 'quality' management, Sociology 34(4): 421-436. doi: http://dx.doi. org/10.1177/S0038038500000274.

Kälvemark, S., Höglund, A. T. and Hansson, M. G. (2004) Living with conflicts - ethical dilemmas and moral distress in the health care system, Social Science and Medicine 58: 1075-1084. doi: http://dx.doi.org/10.1016/S0277-9536(03)00279-X.

Lawton, A. (2005) Public service ethics in a changing world, Futures 37: 231-243. doi: http:// dx.doi.org/10.1016/i.futures.2004.03.029.

Lazarus, R. S. and Folkman, S. (1984) Stress, Appraisal and Coping, New York: Springer.

Lee, K. J. and Dupree, C. Y. (2008) Staff experiences with end-of-life care in the pediatric intensive care unit, Journal of Palliative Medicine 11(7): 986-990. doi: http://dx.doi. org/10.1089/ipm.2007.0283.

Lipsky, M. ([1980]2010) Street-Level Bureaucracy. Dilemmas of the Individual in Public Services, New York: Russell Sage Foundation.

Lomis, K. D., Carpenter, R. O. and Miller, B. M. (2009) Moral distress in the third year of medical school; a descriptive review of student case reflections, American Journal of Surgery 197(1): 107-112. doi: http://dx.doi.org/10.1016/j.amjsurg.2008.07.048.

McBeath, G. and Webb, A. (2002) Virtue ethics and social work: being lucky, realistic and not doing ones duty, British Journal of Social Work 32: 1015-1036. doi: http://dx.doi. org/10.1093/bjsw/32.8.1015.

Merton, R. K., Fiske, M. and Kendall, P. L. ([1956] 1990) The Focused Interview. A Manual of Problems and Procedures, New York: Free Press.

Pollitt, C. and Bouckaert, G. (2004) Public Management Reform. A Comparative Analysis, Oxford: Oxford University Press.

Page, D. (2015) Teachers' personal web use at work, Behaviour and Information Technology 34(5): 443-453. doi: http://dx.doi.org/10.1080/0144929X.2014.928744.

Raines, M. L. (2000) Ethical decision making in nurses relationships among moral reasoning coping style, and ethics stress, JONA's Healthcare Law Ethics and Regulation, 2(1): 29-41. doi: http://dx.doi.org/100888423.

Rajan-Rankin, S. (2014) Self-identity, embodiment and the development of emotional resilience, British Journal of Social Work 44: 2426-2442. doi: http://dx.doi.org/10.1093/bjsw/bct083.

Rose, N. (1999) Powers of Freedom: Reframing Political Thought, Cambridge, New York etc: Cambridge University Press.

Schwenzer, K. J. and Wang, L. (2006) Assessing moral distress in respiratory care practitioners, Critical Care Medicine 34(12): 2967-2973. doi: http://dx.doi.org/10.1097/01. CCM.0000248879.19054.73.

Silverman, D. (1985) Qualitative Methodology and Sociology: Describing the Social World, Aldershot: Gower.

SOU. (2008:51) A Dignified Life in the Elderly Care. Petition of the Dignity Investigation. Available at: http://regeringen.se/download/0c31a755.pdf? major=1\&minor=106288\& cn=attachmentPublDuplicator 0 attachment.

Sporrong, S. K., Hoglund, A. T., Hansson, M. G., Westerholm, P. and Arnetz, B. (2005) 'We are white coats whirling round'-moral distress in Swedish pharmacies, Pharmacy World and Science 27(3): 223-229. doi: http://dx.doi.org/10.1007/s11096-004-3703-0.

Sundström-Frisk, C. and Weiner, J. (2005) What do the occupational injury statistics tell us? In R. Gustafsson and I. Lundberg (Eds.), Worklife and Health in Sweden 2004, Stockholm: National Institute for Working Life, pp. 79-106.

Swedish Work Environment Authority (2015) Work-related Disorders 2014. Available at: https://www.av.se/globalassets/filer/statistik/arbetsmiljostatistik-arbetsskador-2014rapport-2015-01.pdf. 
The Swedish Code of Statutes (2007:1030) Enactment with Instruction for the Swedish Public Employment Service. Available at: http://www.riksdagen.se/sv/Dokument-Lagar/ Lagar/Svenskforfattningssamling/Forordning-20071030-om-arbet sfs-2007-1030/? bet $=2007: 1030$.

The Swedish National Agency for Education (2011a) Curriculum for Compulsory School, Preschool Class and the Leisure-Time Centre 2011. Available at: http://www.skolverket. se/publikationer?id $=2687$.

The Swedish National Agency for Education (2011b) Curriculum, Graduation Objectives, and Joint Upper Secondary School Subjects for Upper Secondary School 2011. Available at: http://www.skolverket.se/publikationer?id=2705.

The Swedish Public Employment Service (2012) The Swedish Public Employment Service Annual Report 2011. Available at: http://www.arbetsformedlingen.se/download/18. 4c507a4c135613b5bc180006795/AF Arsredovisning_2011.pdf.

Thomas, R. and Davies, A. (2005) Theorizing the micro-politics of resistance: New Public Management and managerial identities in the UK public services, Organization Studies 26(5): 683-706. doi: http://dx.doi.org/10.1177/0170840605051821.

Vabø, M. (2006) Caring for people or caring for proxy consumers? European Societies 8(3): 403-422. doi: http://dx.doi.org/10.1080/14616690600821990.

Vabø, M. and Szebehely, M. (2012) A caring state for all older people? In H. Anttonen and K. Stefansson (Eds.), The New Welfare State: Rethinking Universalism and Diversity, Cheltenham: Edward Elgar, pp. 121-143.

Wilkinson, J. M. (1988) Moral distress in nursing practice: experience and effect, Nursing Forum 23(1). 16-29. doi: http://dx.doi.org/10.1111/i.1744-6198.1987.tb00794.x.

Yakhlef, A. and Essén, A. (2012) Practice innovation as bodily skills: the example of elderly home care service delivery, Organization 20(6): 881-903. doi: http://dx.doi.org/ $10.1177 / 1350508412458535$. 